\title{
THE IMPACT OF MALE MIGRATION FROM MOROCCO TO EUROPE ON WOMEN: A GENDER APPROACH
}

FATIMA SADIQI ${ }^{1}$

MOHA ENNAJI ${ }^{1}$

\begin{abstract}
This paper offers a gender approach to the impact of male migration from Morocco to Europe on women left behind. The pertinence of the topic stems from the fact that very few studies have been conducted on the subject. It is believed that such studies will help in the understanding of the the phenomenon of migration and help to find solutions for some of the problems it poses. More and more Moroccan women suffer as a result of the migration of their husbands, sons, fathers, etc. Their suffering is not only due to separation from the loved ones but also to the dire economic and social conditions that a heavily patriarchal context does not help to alleviate.
\end{abstract}

Key words: Effects of immigration upon sending countries, Moroccan women, gender

Resumo - Impactes da imigração masculina de Marrocos para a Europa nas MULHERES QUE FICAM: UMA ABORDAGEM DE GÉNERO. Este artigo efectua uma abordagem de género à questão do impacte da emigração masculina de Marrocos para a Europa sobre as mulheres que permanecem no país de origem. A pertinência desta questão resulta directamente da escassez de estudos sobre o tema. Considera-se que tais estudos poderão contribuir para a compreensão do fenómeno das migrações e ajudar a conceber soluções adequadas para alguns dos problemas por elas suscitados. São cada vez mais as mulheres marroquinas que sofrem em resultado da emigração dos seus maridos, pais, filhos, etc. Esse sofrimento deve-se não só à separação dos seus entes queridos, como também às duras condições económicas e sociais em que se encontram - e que um contexto acentuadamente patriarcal não contribui para atenuar.

Palavras-chave: Efeitos de imigração nos países de origem, mulheres marroquinas, género.

1 University Sidi Mohamed Ben Abdellahof Fez, Fez, Morocco. Email: estry@fesnetmenara. net.ma. 


\section{INTRODUCTION}

Research in the field of migration in Morocco is relatively thriving, yet research on the impact of this migration on women is still very scarce. Male migration has made a great impact on the women left behind. In order to understand the extent of this impact we need to be informed about the profile of the migrant, the situation of women and the way their survival is seen within the overall Moroccan socio-cultural context. Moroccan women constitute a complex category where various variables, such as social class and level of education, are at stake. In order to understand this impact we need to understand the nature of Moroccan migration. In this paper, we have surveyed the major impacts of migration on women, while hoping that this work will attract more research in the field.

\section{MOROCCAN MIGRATION}

\section{A Brief Review of the Literature}

In theory, migration is the movement of human beings from one region to another or from one country to another. As such, migration may be voluntary or compulsory, internal or external (international), individual or collective, and legal or illegal. Migration has been attested to throughout the history of human kind and has developed in extent and nature with the evolution of human communities. According to the mainstream literature on migration (THOMAs, 1961; APPLEYARD, 1988; ANTHIAS, 1998), migration always engenders complex consequences, especially for the host countries. This literature shows that, although migration concerns a relatively small portion of the overall population of a country, it has an everlasting impact on the environment in which migrants settle. After the Second World War, migration has greatly increased and, currently, it remains on the rise (CASTLES and Miller, 2003).

There are many theories of migration but hardly any global explicative ones. There are only partial, mainly classificatory, theories of migration, the main reason being the sociological nature of migration. Indeed, the particular sociological conditions of various waves of migrants makes it difficult, if not impossible, to offer a unique universal explicative theory of migration. In this respect, of interest is the social science approach to migration (MASSEY et al., 1998; SASSEN, 1988; FAIST, 1997; ARANGO, 2000). These studies explain international migration in global terms by stressing the role of economy, sociology and geography. Progress in the understanding of migration is said to largely depend on empirical sociological research.

However, in the present state of affairs, most of this research seems to be located in the host countries (Europe and Canada) and very little is produced in the countries from which migration originates (i.e. Morocco, Algeria and 
Tunisia). In dealing with the impact of migration on Moroccans left behind, the present paper is an attempt to partially fill this gap, open paths for further research, and help in better understanding the diversity and complexity of migration as a concept. It is high time that views of researchers belonging to both host countries and countries of origin be exchanged and synthesised especially in present times when migration is becoming one of the key international issues, not only culturally but also economically and politically.

In principle, Moroccan migration may be internal (from rural to urban areas) or external (from Morocco to Western countries, especially European ones). It is often the case that external migration is an extension of internal migration (see ChatTou, 1998; NoIn, 1970; PASCON, 1986). In this paper, only external migration is considered. Moroccan migration is predominantly male, at least in its initial phases. The dynamic of this migration has always responded to national and international socio-economic and political imperatives. The genesis of Moroccan migration shows that it is a relatively recent phenomenon (Chattou, 1998; Hamdouch et al., 1981). It is characterised by a steady historical evolution and a diversity of destinations. This migration may be broadly categorised into four major phases: (i) pre-Second World War, (ii) post-Seond World War, (iii) the 1960s and 1970s, and (iv) the 1980s to the present time.

\section{Pre-Second World War migration}

Migration started in Morocco at the time of the First World War. This first recorded migration was the result of a specific geo-political and economic context: most migrants of this period originated from the south of Morocco and targeted France to take up jobs that either French men left in order to serve in the army or that were unwanted by the French. No reliable statistics on these migrants are available. All that has been mentioned is that this migration was temporary and most migrants came back to Morocco after the war (CHAтTоU, 1998). The economy of Europe during this period was not flourishing. Many of the migrants who targeted Algeria settled there. Most of these migrants were forced to return to Morocco following Algeria's aggressive policy with Moroccan residents in Algeria after the conflict between Morocco and Algeria over the Western Sahara. The expelled Moroccan migrants were reintegrated in Moroccan society by the Moroccan government.

\section{Post-Second World War migration}

Before the Second World War, in the 1930s and 1940s, Moroccan migrants targeted the Maghreb (especially Algeria) and Western Africa (especially Senegal and the Ivory Coast) (Amin, 1974; AMSELle, 1976; AZAM, 1951; BAROUdi, 1978). According to СнаттоU (1998), most of these migrants originated from Eastern Morocco (i.e. Oujda, Berkane), were tradesmen in the great majority of cases, and were not very young (35 years of age or more). However, like migration before the Second World War, this migration was temporary. 


\section{The $1960 \mathrm{~s}$ and $1970 \mathrm{~s}$}

Moroccan migration witnessed a period of stagnation from 1954 to 1962. However, this migration started to gradually take on larger proportions in the 1960s and 1970s. Pre- and post-Second World War migration changed from being temporary to being permanent in this period, and involved all social categories, not only tradesmen. A great wave of migrants from both the south and the north of Morocco targeted Europe, mainly France, the Netherlands, Belgium and Germany. Most of these migrants originated from the Rif region and spoke Berber as their mother tongue. The migrants of the 1960s and 1970s were younger and more rural in origin. As most of these migrants were single, family reunification drew more migrants. Migration started to be both permanent and illegal. In fact, in prior waves of migration, migrants left Morocco both legally and illegally, and the host countries were tolerant, as Europe needed manpower and jobs were available.

It is worthy to note that, in the 1960s, important waves of Moroccan migrants targeted Libya, following bilateral accords between Morocco and Libya.

\section{The 1980s to the Present Times}

From the 1980s onward, migration has been characterised by a spectacular increase in the number of migrants and a diversity of destinations. In addition to France, the Netherlands, Belgium and Germany, migrants target Spain and Italy. Economic crises worldwide have resulted in soaring unemployment in Morocco. According to recent official statistics, the overall unemployment rate in Morocco in 2001 was 14.5 per cent. Despite Morocco's overall economic progress, poverty is on the rise as a result of globalisation. In the eyes of migrants, the proximity of a prosperous Europe ${ }^{2}$ makes the dream of overcoming poverty possible to realise. On the other hand, dramatic international events such as the fall of the Soviet Union and the rise of fundamentalism in both Europe and the Maghreb have increased both migration and feelings of insecurity, hostility, and xenophobia. In spite of this, Moroccan migration has never ceased to increase. According to the Ministry of Foreign Affairs (1984), no less than 73.9 per cent of Moroccan migrants targeted Europe. Likewise, according to the ministry responsible for Moroccans living in Europe (1992), this percentage reached 77.5 per cent. These figures do not take into consideration illegal migrants and Moroccans who became European citizens by virtue of being born in one of the Europe countries or by acquisition of citizenship in one of them. The latter two types of Moroccan migrants are considered to be 'Moroccan' by Moroccan officials.

2 There is a wide discrepancy between the income of the inhabitants of the southern part and those of the northern part of the Mediterranean. The income per capita in Morocco is 19 times less than in Western Europe. 
From the 1980s onward, the increase in migration was counterbalanced by the implementation of the visa-waiver and the Schengen agreement that reinforced control over migrants coming from Morocco to Europe. This resulted in a spectacular spread of new forms of illegal migration that rendered migration more complex. For example, illegal or clandestine migration is encouraged by clandestine European and Maghrebian traffickers and is so widespread that it is difficult to measure, given its illegality and a total absence of statistics.

From the 1980s onward, migrants are characteristically single (see СнаттоU, 1998; Hamdouch, 1981), young (60 per cent are less than 25 years of age (Chatтou, 1998), poor and/or unemployed.

This period of migration has also witnessed significant changes: whereas migrants of the 1960s and 1970s stayed longer in the host countries, those of the 1980s onward stay for shorter periods of time, given the lack of availability of full-time jobs (СнаттоU, 1998). This has resulted in more frequent visits to the country of origin. This fact reveals the non-integration of these migrants in the European environment and their attachment to their country of origin. This is in concordance with the fact that migrants tend to leave their families behind. ${ }^{3}$

At the present, Moroccan migration is the most widely spread throughout Europe, following Turkish migration. For example, Algerian and Portuguese migrations have targeted France as their main destinations. Moroccan migration is also one of the most sociologically varied; it includes (i) poor migrants, (ii) middle and upper class unemployed migrants, and (iii) professionals.

So far as facilities offered by the host countries are involved, there are important differences. For example, in the Netherlands, the State's highly-developed social policies are often misunderstood by the Moroccan migrants who capitalise on a socialisation of children based on strict behaviour where corporal punishment is not banned. These migrants are often very reluctant to allow for the State's immersion in their private lives or that of their children who, because they have Dutch nationality, have to abide by a specific code of social conduct vis-à-vis the host population. France is more familiar to migrants because of the language and the presence of relatives and friends who happen to be there already, but suburbs are not always an ideal place in which to live. As for Spain, it figures last in the hierarchy of imaginative representations for migrants because of the prevailing negative stereotypes: Moroccans remain los moros, relegated to the poorest housing and to the lowest paying jobs. Italy is often considered by migrants as a land of tolerance and opportunity.

At the end of this review on Moroccan migration, a quick note on female migration (in the sense of women migrating on their own) is in order. Female migration must have always existed alongside male migration although no official figures relating to it are available. It is important to note in this respect that

3 There are migrants who are educated and are professionals, some of whom are well-off but migrate because they find Morocco rather underdeveloped and difficult in which to live because it lacks facilities and prospects for the future are dim. These will not be considered in the paper. 
the Moroccan national media (i.e. television, newspapers, etc.) occasionally report that one or more young Moroccan women are among the dead when small boats carrying clandestine migrants from Morocco to Spain sink. These women are, in general, very young, unemployed and single. Furthermore, the media also report on the abominable conditions in which clandestine migrants live and shows pictures of young men and women living in shantytowns around agricultural areas in Spain. The women who spoke to the reporters often said that they migrated because they wanted to support their ageing parents and younger siblings. Research in this particular area is sorely needed.

\section{THE GENERAL PROFILE OF THE MOROCCAN MIGRANT}

The profile of the Moroccan migrant may be described by taking into account the variables of age, geographic origin, class, level of instruction, marital status, socio-economic situation before migration, skills, size of household, and duration of migration.

Available studies show that, so far as age is concerned, migrants are usually young: their average age is 28.5 years, with 75 per cent of them being between 20 and 39 years old. As for their geographic origin, migrants may originate from rural or urban areas: 60 per cent were born in rural areas and only came to the city on their way to Europe. Concerning class, most migrants belong to the poorest sections of Moroccan society, coming from slums and medinas ${ }^{4}$. A great portion of migrants lives in traditional houses. The average rate of migration per family is 1.72 in cities, 1.12 in slums, and 1.00 in medinas (СнаттоU, 1998).

Concerning the marital status of migrants, some marry before migrating. So far as migrants' level of education is concerned, it is weak before migration in comparison to the total population of the same age in Morocco. Urban migrants tend to have a better level of education than rural ones. As for the professional activities of migrants, they come from backgrounds in the agricultural sector, commerce, services, construction, industry, and traditional skills. The level of education and the degree of skill have improved in the last decades.

The duration of migration depends on whether migrants originate from rural or urban areas, whether the migrant is a head of a household, literate or illiterate, etc. Migrants originating from rural areas stay twice as long in Europe than those originating from urban areas because they can do hard labour. The level of education is pertinent here, as illiterate migrants stay longer than literate ones. Furthermore, agricultural workers do not stay long in comparison with migrants who have other qualifications because they are strongly attracted to their homeland.

${ }^{4}$ Medinas are the old, traditional parts of Moroccans cities, characterised by dense settlement, commerce and labrynthine streets. They exist in contrast to the new parts of the cities that were oftentimes planned and constructed by the French during the time of the Protectorate, parts characterised by wider streets and more 'western' layouts. 
The composition of the household is subject to change in comparison with non-migrant households in the sense that they contain fewer nuclear families. In migrant households, mothers seem to have children at a later age because with late marriages. A study of the employment rates of those living in migrant households shows that 3 per cent of women in both migrant and non-migrant households work.

The decision to migrate from Morocco to Europe may be a matter of individual motivation. In principle, males migrate from regions that are variably rich or poor, and where production factors (i.e. work, capital, natural resources) are not distributed equally (AMIN, 1974). Natural resources (land) are stable, but work and capital are mobile as a result of the adopted development policy. On the other hand, the decision to migrate may not depend on individual will; migrants may neither choose to migrate nor choose the place where they migrate.

\section{THE OVERALL SITUATION OF MOROCCAN WOMEN}

Moroccan women may be classified into two large categories: rural and urban. According to the most recent official statistics ${ }^{5}$, women constitute 51 per cent of the Moroccan population, 65 per cent of whom are illiterate and 74 per cent are young. Women constitute 35 per cent of the employed population, and 35 per cent of the unemployed. Widows comprise 11 per cent of women and 4 per cent are divorced. Women-headed households are on the rise.

Rural and urban women share a common denominator: poverty. The dichotomy 'rural/urban women' is useful as it reflects two categories of women that are affected differently, given that they do not stand the same chances of having a proper education, claiming their rights, benefiting from modernisation, etc. Additionally, the rural environment does not allow for the adoption of the same types of strategies in the face of migration.

Although rural women participate in agricultural production, they are still considered 'housewives' or 'family helpers'. It is only very recently that these women are listed in statistical accounts as 'workers' or 'producers'. This illustrates the extent to which rural women's work is underestimated. This attitude still holds nowadays, as several types of goods and services produced or offered by women are badly-paid activities.

The impact of migration on women is directly related to the overall sociocultural context as well the development status of both the countries of origin and the host countries. In order to assess this impact, we need first to have a view of the overall situation of Moroccan women.

5 See Bureau des Statistiques, Rabat, 1999. 
Moroccan women do not constitute a homogeneous group. They may be socially categorised along six parameters (SADIQI, 2002): geographic origin (urban vs. rural), class (rich vs. poor), education (educated vs. uneducated), job opportunity (working vs. non-working), language skills (multilingual vs. monolingual), and marital status (married vs. non-married). These social categories are not clear-cut or easily discernable; they may be best qualified as loose 'bundles' of social 'traits' that may themselves be subject to further sub-categorisation. In fact, the two poles of each social category constitute extremities of a spectrum of 'social states' and the area between the extremities is filled with relative 'nuances' of either pole. For example, the boundaries between urban and rural areas in Morocco are not always discernable in a straightforward way by virtue of the fact that semi-rural and semi-urban areas, which combine characteristics of both, exist and are operative. Furthermore, the difference between women that qualify as 'rich' and the ones that qualify as 'poor' is relative given the existence of the categories 'less rich than...' and 'less poor than...'. The same degree of flexibility is attested in the oppositions 'educated/non-educated', 'working/non-working', 'multilingual/monolingual', and 'married/non-married'.

So far as geographic origin is concerned, rural and urban women relate differently to language, space, traditions, household economy, and education. Rural women are more associated with orality and illiteracy in the wider Moroccan socio-cultural context that favours modernisation, literacy, and multilingualism. Furthermore, unlike in urban areas, rural communities are often organised in simpler but larger sizes. Consequently, large families often result in everyone knowing everyone else within local communities. It is this social organisation that explains the fact that women in rural areas are more 'watched' but, on the other hand, less subject to public sexual harassment, than urban women. The rural social organisation is also characterised by less anonymity in public space, a fact that strengthens the grip of patriarchy as women often fall under the 'protection' of any male member of their community. Likewise, generally speaking, rural women in Morocco are more often victims of traditional customs, rigid kinship relations, and a strong code of honour than urban women. For example, these women are more affected by early marriages, multiple pregnancies (especially in the absence of a son), polygamy, and accountability to the larger family and community units. Moroccan rural women as a group rely less on their men's (fathers', husbands', sons') income and participate more in their household economy than urban women. In Moroccan rural areas, there is a sex-based division of labour as men and women are separated in daily tasks (Belarbi et al., 1995; Bourquia et al., 1996; ChlebowsKa, 1990). Rural women's labour includes domestic chores, work in the fields, buying and selling in the suqs (local markets), smuggling goods across borders, and working as maids in urban areas.

A consideration of the types of activities that Moroccan rural women perform reveals that these women are excluded from the benefits of modernisation, as modernisation is essentially urban. For example, investments in the health care and education sectors have benefited urban women more than rural 
ones. The bulk of economic activities is set up in cities and it is through these activities that women have had access to paid work. Rural areas have been neglected and are still based on the traditional economy. This has resulted in relegating rural women to the fringes of society. Lower class rural women are doubly oppressed and exploited by poverty and a rigid gender dichotomy. The ones that are most hit are peasant women and women in densely populated poor urban districts which emerged as a result of rural exodus and constitute an extension of rural areas. Both rural areas and poor urban districts lack sanitary facilities and basic infrastructure. Women in these areas represent the majority of Moroccan women. They survive in painful conditions and suffer most from lack of means and deterioration of the environment.

In spite of all these disempowering factors, rural women in Morocco are not passive; they fight exclusion by forcing their way into the male-dominated public spaces and assert themselves as breadwinners by supporting their households, sometimes single-handedly. The overall status of Moroccan rural women as a group makes them negotiate gender and power relations in a way that is congruent with their socio-cultural environment. Their endeavours are indeed very courageous in a context that is characterised by widespread illiteracy, strong patriarchal dogmas, and a strict gender dichotomy.

Whereas rural areas symbolise tradition in Morocco, urban areas symbolise modernity, social opportunity, and social mobility. Modernity has been concomitant with urban migration in Morocco. It has not benefited all urban Moroccan women. While it allowed relatively well-off women to become educated and functional in the State's modern institutions, poor urban women have not benefited from independence in the same way. Whereas upper and middle class women generally worked outside the home as a result of years of education and felt proud of their work, poor women worked outside the home out of necessity and were not generally proud of this work. The former's work was officially recognised and even encouraged because these women constituted part of the elite. Whatever the motives for Moroccan women's work outside home, their work has always been widely considered instrumental as a token of modernity in Morocco.

Moroccan urban women started to participate in the household economy in the 1930s. Their work was not an act of militantism but rather a result of poverty, because most of these women worked as maids in the French or upper class Moroccan households or were recruited as low-paid workers doing menial jobs in fields or factories. However, a few Moroccan urban women managed to create their own enterprises in the 1930s and 1940s in cities (see BELARBI, 2001). After Morocco's independence, a growing number of Moroccan urban women were incorporated into the 'official' labour market. Women's employment rates in urban areas increased steadily - 5.6 per cent in 1960, 10.8 per cent in 1971, 14.7 per cent in 1982, and 17.3 per cent in 1994, according to the general statistics of the Ministry of Population and Housing. Furthermore, the rate of feminisation of the labour force (15 years of age and more) grew during independence 
and reached 33 per cent in 1990. Women's work in industry greatly helped Morocco's development. The greatest majority of salaried women has and still constitutes the lower and middle rungs of the job ladder. Very few women have managed to reach top positions in their jobs.

In addition to salaried jobs, personal and domestic services have been highly feminised in urban areas. The more urban women take jobs outside the home, the more domestic services they need in households to keep the balance between outside work and daily domestic chores. According to MERNISSI (1982), in 1971, a quarter of maids were children (under 15 of age). In 1993, this percentage went down by about 10 per cent. Maids receive small salaries that differ per family. Maids are not only economically marginalised, they are also marginalised by the law, as they are neither included in the work legislation nor in social security. Most very young domestics are not paid directly; the money they earn goes directly to their parents.

It is commonly the housewife who pays the maid. In this way, housework primarily remains the responsibility of women: it is shared by women of different social classes (the housewife and the maid) who sometimes belong to different age groups (housewives are usually older than domestic servants). It is as if urban women's participation in the household economy and their integration in official development depends on the exclusion of other women who come from rural or poor urban areas to work as maids. However, paradoxically, it is urban women in various political parties and civil society that fight to improve the social status of maids by incorporating the maid status in the Work Code (Code du Travail). These militants also call for a strict application of the work law that forbids recruiting children under 12 years old and under 14 years old without the consent of their parents. Indeed, as maids are hired on the basis of 'minimal wages for maximum service', service relations between women is nowadays characterised by an emerging struggle for independence and identity in the labour force for both maids and their employers. This is also a struggle for social recognition of rights in the face of gender and class prejudice (see MERNISSI, 1982).

Given these facts, urban and rural women are not given the same choices in the economy (see FolBRE, 1994) and, hence, resist patriarchy differently. Economically well-off urban women often exploit economically-weak rural women. Furthermore, as a social group, urban women are offered more chances to acquire an education than rural women, and hence, the former have more access to language skills and job opportunities than the latter. It is on the basis of this asymmetry in chances that rural women are socially categorised as 'subordinate' to urban women.

As a social category, class is based on social and personal network ties (see Milroy and Milroy, 1992). It is through these network ties that interactions create class. Like geographic origin, class is a social variable along which Moroccan women are categorised into groups. Class is, thus, a social factor that explains the heterogeneity of Moroccan women. The modern capitalist system 
created the 'modern' Moroccan type of class system (upper, middle, and lower classes). The impact of class varies from urban to rural areas. In the former case, class is often manifested in the quality of the houses, outward appearance, and the extensive use of French as a sign of literacy, whereas in the latter case, class is manifested in the amount of land, livestock, and property. In the postcolonial Moroccan system, urban, middle and upper class girls acquired an education, and sometimes a profession, which they exercised more out of social prestige than out of necessity. However, although belonging to upper and middle classes gave more opportunities to women to assert themselves in the public sphere, these women remained locked into the capitalist class patriarchy, as men continued to control the key institutions of power. In this patriarchal context, labour and class differences that accompanied modernisation materialised in two different and incompatible worlds: the world of men and the world of women. Whereas the world of women was characterised by 'introverted-ness' as it was turned towards 'inward' domains such as the home, the world of men was 'extroverted' as it was turned 'outwards' towards the public domains that guaranteed prestige and power. The new order that was adopted by the Moroccan upper and middle classes was meant to serve the elite's purposes and, by excluding the larger 'non-elite' portions of the Moroccan society, it re-established the sexual dichotomy and pushed women, once again, to second position.

Although in principle, class is subject to change as women from low classes may get more education or marry into wealthier families, the class system is still very strong in the Moroccan context and women are often first socially categorised as 'rich' or 'poor'. The social variable of class is a strong indicator of heterogeneity among Moroccan women. Class disparities between Moroccan women influence the ways in which these women resist patriarchy and social oppression. Each group of women uses the choices that their class offers them: upper and middle class women use education and sometimes the social position of their husbands, and lower class women often use family ties and the social position of their sons. Educated women are from the outset more socially privileged than uneducated ones; they have more job opportunities, more chances to achieve independence, self-promotion, and self-satisfaction, as well as more freedom to influence the course of events in their lives.

Job opportunity is another social variable that attests to Moroccan women's heterogeneity. Women's jobs vary from menial, to low-paid, to relatively wellpaid. However, women are not often found in top positions of the job ladder. In spite of this, the opposition 'working/non-working' divides Moroccan women and, everything being equal, puts the non-working category at a disadvantage. Women's financial contributions to the household often trigger mixed attitudes, being on the one hand, welcomed as a supplementary source of income and, on the other hand, clashing with the traditional view of women as primarily 'housekeepers'. The idea that Moroccan women work outside their homes clashes with Moroccan socio-cultural values, affects Moroccan women's external image, as well as their inner psychological selves. Moroccan women are generally brought 
up in a traditional Muslim environment that venerates patriarchal values and, thus, find it very difficult to accommodate the image of an obedient and hardworking housewife with a modern and independent career woman.

Working outside the home is often accompanied by all sorts of tensions and stress for which Moroccan women are not often prepared. For example, having a job often involves dressing, appearing, speaking, and behaving in a 'modern' way. These daily gestures are intermingled with a strong social code of behaviour that places considerable pressure on women who often find themselves torn between two clashing systems of values: tradition and modernity. Moroccan women's work creates another paradox: although it is welcomed, it is socially perceived as being the cause of men's unemployment. This is linked to the social attitude towards women's work in Morocco that is still loaded with stereotypes. As a result, Moroccan career women face a dilemma: how to respond to the traditionally masculine norms of the job market and at the same time respond to the traditional feminine role expectations that social norms prescribe? Career women are subject to both the forces of traditional stereotypes and the demands of modern life; they are often 'apologetic' and 'hesitant' in public spheres, because they need to adopt more stereotypically male attributes (i.e. being assertive and task-driven). These women are generally more assertive and forceful in private spheres.

Working women are also more consulted in matters relating to household income management, the education of children, etc. These women are less likely to be in a polygamous marriage than non-working women.

Possessing language skills in the sense of knowing one or more written languages in addition to one's mother tongue is highly viewed in Moroccan society, where multilingualism constitutes a strong cultural component. The mastery of language skills in the Moroccan context is a socially positive factor that may serve to either empower or disempower women. Mastering language skills allows them to resist patriarchy in different ways: multilingual women use written languages to assert themselves and fight exclusion in public spheres, whereas monolingual women are restricted to using orality for the same purpose.

Marriage is an important institution in Moroccan society and culture, as well as in the Arabo-Muslim world (see AFsHAR, 1987). The marital status of women is an important social variable that reflects the heterogeneity of Moroccan women and the discrepancy of choices and chances they have. The importance of this variable cuts across geographic origin, class, level of education, job opportunity, and mastery of language skills. Although each one of these social variables has its value in the Moroccan context, none of them reduces the importance of marital status because women in Morocco are first and foremost socially defined in relation to this variable. Marital status divides women into 'married' and 'unmarried'. Whereas the social category of married women is clear, the category of unmarried women is more complex as the latter may be spinsters, divorced, or widows. While social attitude towards married women is very positive, it is rather negative towards the various sub-categories of unmar- 
ried women. Therefore, the social choices and chances that are offered to women in the former category are very different from the ones offered to women in the latter category. This discrepancy in choices shows that Moroccan women are not socially oppressed in the same way. This discrepancy also creates great tension between women inside and outside families. Inside families, where both married and unmarried women live together, more value is given to married women, in the sense that they are more often consulted in matters relating to the everyday running of the household than the unmarried ones.

Having briefly overviewed the major social categories to which Moroccan women belong, it is important to note that these women are far from being passive victims of male migration; they fight back, although in difficult conditions.

\section{THE IMPACT OF MALE MIGRATION ON WOMEN}

Migration makes a great impact on the women left behind. These women may be wives, mothers, sisters, daughters, spinsters, or widows. They may have their own children or be in charge of somebody else's children. The impact of migration on these women may be positive, negative or both depending on the social category to which they belong and the size of the household. This impact is considered in relation to family structure and general behaviour, household economy, and investments (i.e., resources, enterprise, housing, household appliances, etc.).

\section{Positive impact}

A positive impact of migration on women is greater independence in the management of the household economy. The women left behind belong to various social categories, a fact which makes them a heterogeneous group. Widows living with the migrant's siblings and wives with children constitute a sizeable portion of the women left behind. They are illiterate in the great majority of cases. They are, especially the widows, the most likely to manage the household income in the absence of the husband/son. Their age and their 'mother' status bestow great social power on them and society generally accepts their presence in the public (men's) sphere. In addition, the strong relationship that mothers develop with their sons, whom they consider as sources of revenue and support in their old age, especially in the absence of the husband, gives them power. This category of women is most often found in rural and semi-urban areas, more so than in typically urban areas.

As for young, usually newly-married brides, they often live with the migrant's parents, the ones who control the migrant's remittances. This category of women acquires power with the coming of children and most of them manage to join their husbands in the host countries. On the other hand, sisters 
have less access to the migrant's remittances, especially if they are married, unless the mother is absent or dead. Spinsters in the household (who may be sisters or a member of the family) are also taken care of by the migrant.

In addition, migration often results in a restructuring of the family and the emergence of women-headed households in a heavily patriarchal society. The women left behind in cities may start seeking a job. This engenders change in mentality and behaviour and enhances women's agency. For example, women leave the home for day-to-day purchases and manipulate larger expenditures by allocating funds to cover them. They become economic monitors, which significantly influences their overall status.

Another positive impact of migration on women and on the overall development of Morocco in general is its contribution to the development of the country. Indeed, migrants' remittances constitute the primary source of income for the national budget. Migrants' investment in Morocco represented 2 per cent of the country's revenue in 1960, 10 per cent in 1971 and almost 25 per cent by the end of the 1970s (Bureau des Statistiques, Rabat, 1994). The importance of remittances is linked to (i) the temporary nature of migration, (ii) the fact that the migrant is not accompanied by his family, and (iii) the solid family attachment, especially for the migrants who originate from rural areas or from the poorest sections of the Moroccan population. The Moroccan government has started to take important measures to encourage Moroccan migrants to invest in their country of origin. The Mohamed V Foundation for Solidarity is a royal institution whose sole goal is to take care of Moroccan migrants at all levels. The results that the Foundation has achieved up to now are very satisfactory.

The most positive impact of migration on women is the increase in the income of the migrant's household. Having a husband, a son, or a brother as a migrant in Europe is often perceived as a source of income. In fact, the structure of the resources of the migrant households differs from that of non-migrant ones (Chattou, 1998; Courbage, 1994). This is primarily due to the amounts of money that migrants send to their families, whereas salaried work constitutes the major source of income for non-migrant households. These incomes are often stable because of the regularity of jobs in the host countries. For two-thirds of households, the amount of remittances is superior to the minimum wage. This is due to a change in the nature of migration: from a migration of enrichment to a migration of necessity. The amount was multiplied by 5.3 in the $1960 \mathrm{~s}$ and by 13.1 in the 1970 s.

As far as investments are concerned, rural migrants are more attached to their country of origin than urban migrants. Agricultural resources are more important for the former, and enterprise resources are more important for the latter (see Chattou, 1998; Hamdouch et al., 1981). Accordingly, rural migrants invest more in land, while urban migrants invest more in housing and commerce. For both types of migrants, investment provides security.

Migration also has a direct positive impact on the education of children. As Moroccan education is in a transitional period (from public to private educa- 
tion), the migrant's choice of the type of education for his children reflects his vision of the world. It is precisely at this level that modernity and tradition may come into conflict. It is also at this level that the evolution in attitudes between these two poles can be measured. Parents may choose between the following types of education for their children: religious, modern, or short-term professional training. It seems that migrant households would opt more for a modern type of education than non-migrant households. The size of the family, as well as the length of migration, are important variables here. Women play a larger role in influencing the migrant's choice as to the type of education they want for their children. Given that finding a job, especially in the private sector, depends on the mastery of French, women generally opt for the modern type of education. Indeed, so far as their children's education is concerned, the women left behind often function as agents of socialisation, making the participation of men minimal. Many of them realise themselves through their children, especially sons whom they consider as a guarantee of financial security in their old age.

\section{Negative impact}

In addition to the positive impact of migration on women, there is a negative one. In general, migration has a deep destabilising impact on the Moroccan social fabric. It often results in the disintegration of the family nucleus and traditions. While spatial mobility engenders more equity in household relations and promotes the education of children, it increases the rate of divorce and lessens the authority of parents over children. New cultural models that are adapted from industrialised societies deeply affect the traditional roles of men and women in Moroccan society and sometimes result in strong clashes between traditional and modern values.

Another negative effect is related to the overall condition of the women left behind although they may gain in agency and self-esteem. The Department of Statistics (Bureau des Statistiques) has published a study on the state of poverty in Morocco. ${ }^{6}$ Poverty has risen since the 1990 s from 13.1 per cent to 19 per cent. Part of this study focuses on the female population and households run by women, as an example of the poorest sectors in Moroccan society. According to this study, more than 2.7 million women were officially declared poor in Morocco in the year 1998-1999, with an annual increase of 6 per cent. Age is important here: 48.2 per cent (59.1 per cent in rural areas) are under 25 years old, 33.8 per cent (24.1 per cent in rural areas) between the ages of 25 and 44 , and 13.0 per cent ( 16.8 per cent in rural areas) over 45 . This shows that rural women suffer more from poverty than urban women.

Of great significance to this paper is the fact that the marital status of these women is not really significant: 10.1 per cent ( 23.5 per cent in rural areas) of married women in urban areas are poor in comparison to 11.4 per cent $(24.2$ per cent in rural areas) of single women. Households headed by single women represent 30.3 per cent in rural areas and 14.4 per cent in urban areas. House- 
holds headed by mothers represent 8.6 per cent in urban areas and 22.3 per cent in rural areas. Illiteracy is another relevant factor: 89.9 per cent of women in rural areas and 58.2 per cent in urban areas are illiterate according to 1999 official statistics (see Bureau des Statistiques, Rabat).

Serious negative effects of male migration are attested to when the migrant does not find a job or finds a low-paid job in the host country. This situation is becoming increasingly common. This state of affairs may engender more poverty for the women left behind, less education for the children, and changes in the structure of the family (such as divorce) that harm children.

In rural areas, poor women left behind work in the fields, generally in small farms owned by their family. The fact that boys stay in school longer than girls reinforces the need for female labour. Rural women work an average of ten hours a day. In spite of this, it is men who head the farms and who are viewed as full-time labourers no matter how long they stay on the farm. This explains the fact that the rate of women whose work is recognised as such is abnormally low. In 1989, 82.9 per cent of women working in agriculture were counted as family helpers.

Another problem faced by rural women left behind face is their lack of savings. This is mainly due to their inferior status relative to discriminatory inheritance laws. Women's share in land ownership is usually absorbed by male heirs. As a result, these women face difficulty in obtaining bank loans because of lack of guarantees. The devalorisation of women is, thus, perpetuated because of the discrimination sanctioned by law.

Poverty is aggravated by lack of infrastructure, facilities, unemployment, under-employment, and droughts. In Moroccan cities, the social sectors of health care and education are the most hit by budget cuts. Education expenditure per capita decreased by 11 per cent from 1983 to 1989 , resulting in a general decline of 8.7 per cent in school enrolment rates between 1985 and 1990. In a society where female education is considered less important than male education, it is girls who are most directly affected by this decline: the school enrolment rate declined at 7.8 per cent for boys and at 10 per cent for girls. Peasant girls are the worst hit with a decline rate of 13.6 per cent.

Likewise, a great percentage of women left behind is found in the lowest levels of vocational schools: 72 per cent of them have primary school educations and 50 per cent have completed three years in the secondary school. However, females constitute one-third of those in the highest levels of skilled technician training. Despite the recent upsurge of computer training and jobs related to computer science, electronics, hotel business, women still opt for typically female activities, such as dressmaking, embroidery, and secretarial work.

Nowadays, the importance of women's work for the economy of Morocco has become a reality. Households need women's financial contributions in order to survive. Women's work is, however, tolerated only if it does not clash with society's gender role assignment (see SADIQI, 2003). 


\section{CONCLUSION}

A conclusion to this paper would be that the overall social status of Moroccan women left behind by male family members is ambivalent and sometimes paradoxical. These women are both empowered by their new condition and disempowered by their social condition and lack of facilities. Although some of these women, especially the newly married, widows and spinsters follow their male migrant family members, the majority of women stay behind and find themselves burdened with the responsibility of catering for the household, maintaining the family honour and raising children.

In spite of all significant disempowering factors, rural and urban women left behind are not passive; they fight exclusion by forcing their way into the male-dominated public spaces and assert themselves as breadwinners by supporting their households, sometimes single-handedly. The overall status of Moroccan rural women as a group makes them negotiate gender and power relations in a way that is congruent with their socio-cultural environment. Their endeavours are indeed very courageous in a context that is characterised by widespread illiteracy, strong patriarchal dogmas, and a strict gender dichotomy.

In the present state of affairs, migration has indeed become a priority on the Moroccan government's political agenda. A new ministry for the Moroccan residents in Europe has been recently created and a woman was appointed to head the ministry. In spite of the fact that migration has always attracted the attention of decision-makers and in spite of the fact that it constitutes a major source of revenue, almost no attention is being paid to this category of Moroccan women by researchers. Given the general social, economic and political situation in Morocco and Europe and given the great tensions that we have to live with and monitor, it is imperative that the women left behind by migrants are allocated due attention. They do not only guarantee family stability in the absence of males, but they also have a direct and everlasting impact on children. Both the positive and negative impacts of migration on these women need to be seriously taken into account. Women's agency in Moroccan society has been confirmed over the years as the Moroccan feminist movement has shown, but illiteracy and lack of access to the spheres of power still constitute hurdles for them. State assistance for both women and their children will certainly help them carry out their mission more appropriately.

\section{REFERENCES}

Afshar, H. (ed.) (1987) - Women, State and Ideology: Studies from Africa and Asia. Macmillan, Basingstoke, UK.

Amin, S. (1974) - Les migrations contemporaines en Afrique de l'Ouest, Oxford.

Amselle, J.-L. (1976) - Les Migrations africaines. Éditions Maspéro, Paris.

Anthias, F. (1998) - Evaluating "Diaspora": Beyond Ethnicity, Sociology, 32(3): 557-580. 
APPleyard, R. (1988) - International Migration Today: Trends and Prospects. Vol. I. Unesco/University of Western Australia, Paris.

ARAngo, J. (2000) - "Explaining Migration: A Critical View", International Social Science Journal, vol. 52: 283-296.

AzAM, P. (1951) - L'Emigration temporaire au Maroc Oriental. CHEAM, Rabat.

BARoudi, A. (1978) - Maroc. Impérialisme et émigration. Éditions Le Sycomore, Paris.

Belarbi, A. (ed.) (2001) - Femmes et démocratie. Le Fennec, Casablanca.

Belarbi, A. et al. (eds.) (1995) - Femmes rurales. Approches. Le Fennec, Casablanca.

Bourouia R. et al. (eds.) (1996) - Femmes, culture et société au Maghreb. Afrique-Orient, Casablanca.

Castles, S.; Miller, M.-J. (2003) - The Age of Migration: International Population Movements in the Modern World, $3^{\text {rd }}$ edition, The Guilford Press, New York.

Chatтou, Z. (1998) - Migrations Marocaines en Europe. Les paradoxes des itinéraires. L'Harmattan, Paris.

ChLebowska, K. (1990) - L'Autre Tiers-Monde: Les femmes rurales face à l'analphabétisme. UNESCO, Paris.

Courbage, Y. (1994) - Demographic change in the Arab world: the impact of migration, education and taxes in Egypt and Morocco. Middle East Report, September-October.

Dallot, L. (1970) - Les Migrations humaines. P.U.F., Paris.

Duchac, R. (1980) - La Sociologie des migrations aux États-Unis. Mouton, Paris.

EL-FAssi, A. (1979) - L'Autocritique (in Arabic). Éditions Ar-rrisalah, Rabat.

FAIST, T. (1999) - Transnationalization in international migration: implications for the study of citizenship and culture. Presented at the UNESCO International Conference. Warwick, Coventry, UK.

Folbre, N. (1994) - Who Pays for the Kids? Gender and the Structures of Constraints. Routledge, New York.

Hamdouch, B.; BerRada, A.; Baddou, T.; Lassonde, L. (1981) - Migration internationale au Maroc. Institut National de Statistique et d'Économie Appliquée, Rabat.

MASSEY, D. et al. (1998) - Worlds in Motion. Understanding International Migration at the End of the Millennium, Clarendon Press, Oxford.

Mernissi, F. (1982) - Virginity and Patriarchy. Women's Studies International Forum: Women and Islam, 5 (2): 183-191.

Milroy, L.; J. Milroy (1992) - Social Network and Social Class: Toward an Integrated Sociolinguistic Model. Language in Society, 21: 1-26.

Noin, D. (1970) - La Population rurale du Maroc, Geography thesis, Université de Paris I.

Pascon, P. (1986) - Capitalism and Agriculture in the Haouz of Marrakesh. Kegan, London.

SADIQI, F. (20032) - Women, Gender and Language. Brill Academic Publishers, Leiden.

Tномаs, B. (1961) - International Migration and Economic Development. A Trend Report and Bibliography. UNESCO, Paris. 